\title{
Appraisal of Awareness and Implementation Levels of Energy Efficiency Design Strategies for Office Buildings in Abuja, Nigeria
}

\author{
E. M. Erebor*, E. O. Ibem, I. C. Ezema, A. B. Sholanke \\ Department of Architecture, Covenant University, Ota, Ogun State, Nigeria \\ Received February 9, 2021; Revised March 25, 2021; Accepted May 16, 2021
}

\section{Cite This Paper in the following Citation Styles}

(a): [1] E. M. Erebor, E. O. Ibem, I. C. Ezema, A. B. Sholanke, "Appraisal of Awareness and Implementation Levels of Energy Efficiency Design Strategies for Office Buildings in Abuja, Nigeria," Civil Engineering and Architecture, Vol. 9 , No. 4, pp. 1084-1096, 2021. DOI: 10.13189/cea.2021.090411.

(b): E. M. Erebor, E. O. Ibem, I. C. Ezema, A. B. Sholanke (2021). Appraisal of Awareness and Implementation Levels of Energy Efficiency Design Strategies for Office Buildings in Abuja, Nigeria. Civil Engineering and Architecture, 9(4), 1084-1096. DOI: 10.13189/cea.2021.090411.

Copyright $\odot 2021$ by authors, all rights reserved. Authors agree that this article remains permanently open access under the terms of the Creative Commons Attribution License 4.0 International License

\begin{abstract}
Energy efficient buildings are buildings that consume less energy while also maintaining or improving the comfort conditions for their occupants, compared to the normal building type. Such buildings result not only in less negative impact on the environment, but are economically sustainable and resilient. This study investigated the extent to which building professional firms in Abuja, Nigeria are aware and implement the different energy efficiency design strategies available for deployment in office buildings, in order to ascertain the current level of knowledge and implementation of the strategies within the building industry in the study area. A structured questionnaire was used to gather data from 80 professionals drawn from architectural and engineering firms involved in the design of office buildings in the study area. The data were analysed by descriptive statistics and the results indicate that both the awareness and implementation levels of energy efficiency design strategies by the firms are high. Whereas most (78\%) of the respondents are aware of the various energy efficiency design strategies employed in office building designs, few $(22 \%)$ of them have little or no knowledge of the strategies investigated. On the implementation level, majority (69\%) of the participants recorded a high rate, while few (31\%) recorded a low rate. The study also found that the strategies the firms are mostly aware of are site planning, natural ventilation and building orientation. Whereas, the three most adopted strategies among the strategies investigated
\end{abstract}

are: building plan and space organisation; site planning and building orientation. Among the recommendations of the study is that relevant stakeholders of the building industry in the country, should provide platforms from time to time for promoting the benefits of energy efficiency design strategies in the country, in order to maintain the high level of understanding and deployment of the strategies by the building professionals that currently exist in the study area. This is envisaged to ultimately lead to curtailing the adverse effects of global warming on the environment in the long run.

Keywords Energy Efficiency Design, Office Buildings, Building Professional Firms, Abuja and Nigeria

\section{Introduction}

Approximately $90 \%$ of our time is spent in buildings, either at home or in the office. Oftentimes, a high amount of energy is needed to run and maintain the buildings. [14] believe that buildings in the long run play a very vital role in global energy consumption and carbon dioxide emissions which result in adverse consequences of global warming. Ways of conserving energy in buildings have therefore become important considerations in the design and development of modern structures that are energy 
efficient. Energy efficient buildings are now the way to go in the design and construction of office buildings in the $21^{\text {st }}$ century. This has arisen from great concerns in the world about the effects of buildings on the environment and on users and their comfort levels within them [21]. According to the Energy Efficient Office Guidelines for Nigeria 2014, energy efficient buildings are buildings that consume less energy and at the same time maintaining and improving the comfortability of the users within the buildings [16]. Office buildings consume a lot of energy during construction and occupation and this has adverse consequences directly on building users and their comfort levels can be affected, while also affecting the immediate surroundings of the buildings. It is therefore important to develop modern day office buildings as energy efficient buildings.

Due to the importance of conserving energy in present day office buildings, some studies were found to have been conducted towards promoting the development of energy efficient buildings, as well as developing better ways of conserving energy use in buildings. For instance, [41] advanced a new photonic crystals glazing (PCG) system that can be controlled dynamically to achieve a high reflection of NIR without having to affect visible light transmission in their study on "energy efficiency of smart windows made of photonic crystal". Compared to existing glazing systems, the authors found that the PCG is the most energy efficient system to reduce cooling and heating loads. The system was also found to save more energy in cold climates with high heating loads. In a recent study on "factors impacting integrated design process (IDP) of net zero energy buildings" [25], it developed a framework useful for researchers for comparing IDP implementation between projects and for design teams for training on design management and IDP. Likewise, in another recent study on impact assessment of window to wall ratio (WWR) on the consumption of energy in office buildings in Bangladesh, a subtropical monsoon climate, [30] recommended an optimum range of WWR of $30 \%$ to $40 \%$ for air-conditioned office buildings in the study area. This was because existing office buildings were found to save up to $9.40 \%$ of electricity through the incorporation of the optimum percentage range of WWR.

As a result of the importance and growing need of incorporating energy efficiency design strategies in buildings, some studies were also found to have contributed to the subject in Nigeria. [6] examined electricity use in mechanically cooled commercial office complex in five major cities in Nigeria using computer software packages. [28] highlighted the need for using energy efficiently in buildings in the country. According to the author, renewable energy use is completely absent in the Nigerian building industry. The author suggested that governments at all levels in Nigeria should embark on enlightenment campaigns on the importance of using energy efficient strategies within buildings. It is important to note that effective energy use ensures optimum air quality and thermal comfort for office users, improves productivity levels for workers in office buildings where people converge daily to get work done. A study by [19] identified the passive and active design strategies and features that were used in areas with extreme weather conditions of the North-eastern part of Nigeria in a research on a building. In a study in Abuja, [1] recommended a successful sustainable improvement of existing public office buildings where facilities should be given more attention from users' perspective than the other design variables.

The various highlighted studies above provided insight into some design strategies implemented in the design and construction of energy efficient buildings towards achieving energy efficiency within them. This goes to show that energy efficient buildings play a vital role in ensuring good working environments, health, comfort and productivity of users. However, [17] noted that there is still not enough research on the subject matter, especially in countries in Sub-Saharan Africa, and thus argued that more work needs to be done on the subject of energy efficiency, the implementation of energy efficiency design strategies in buildings and their effects on users' comfort in buildings. [20], also observed that in Nigeria, there is a lack of awareness among building professionals of the various energy efficiency design strategies that are applicable to office buildings. Where professionals lack adequate knowledge of the various existing energy efficiency design strategies available for use in buildings, it will be difficult to have the built-environment developed to achieve optimal energy conservation when in use.

In Nigeria, previous and present administrations of government have formulated guidelines for the energy sector towards encouraging the reliance on natural energy sources such as renewable energy strategies in building design and development. The strategies that were proposed consist of developing building codes that have energy efficiency as their cardinal goals. The codes took into consideration the use of bioclimatic design concepts and principles and the incorporation of other energy efficiency saving measures that would make office buildings more energy efficient, thereby ensuring user's comfort within them.

Due to the growing importance of finding ways to conserve energy in the development of buildings, some studies were found to have examined energy efficiency strategies in buildings as mentioned earlier [6]; [28]; [19]; [20]. Previous literatures indicate that 29 energy efficiency design strategies have been implemented in various building types. The said strategies when employed in office buildings, usually contribute to enhancing users comfort and help to reduce the adverse effects of the buildings on the environment. However, no research was found to have investigated the extent to which building professional firms in practice are aware of all the various energy efficiency design strategies available for deployment in office 
building designs, especially in a developing country like Nigeria. This is necessary to understand whether those saddled with the responsibility of designing energy efficient buildings are adequately aware of the various design strategies now available for developing energy efficient buildings. It was in an attempt to bridge this gap identified in literature that this study investigated the extent to which building professional firms in Abuja, Nigeria are aware and implement the different energy efficiency design strategies available for deployment in office building, in order to ascertain the current level of knowledge and implementation of the strategies within the building industry in the study area. To achieve this aim, two key objectives were developed for the study. The first is to investigate the awareness level of building professional firms in the study area of the various energy efficiency design strategies available for deployment in buildings. While the second is to examine the extent to which the said firms have deployed the different energy efficiency design strategies in office building designs.

Abuja was chosen as the study area because being the capital of Nigeria, it has a large concentration of building professional firms. Abuja is situated in the north central geopolitical zone of the country. The scope of the study inquiry is restricted to architectural and engineering firms that engage in building developments, as they are the ones involved in designing different aspects of office building, towards conserving energy. Due to the large volume of building firms in Abuja, the scope of the study inquiry was further limited to firms that have handled office buildings situated within the central business district as this area was found to have the highest concentration of office buildings in the study area. The study investigation was further limited to twenty-nine energy efficiency design strategies identified in literature. The study findings are valuable resource materials that contribute to the ongoing discourse on how to develop sustainable buildings that are energy efficient. Subsequent parts of this paper include: literature review, methodology, results and discussion, conclusion, acknowledgments and references.

\section{Literature Review}

\subsection{Concept of Energy Efficiency}

In their study, [3] noted that the primary purpose of erecting a building structure is to provide a habitation or dwelling for man with the aim of protecting him from the vagaries of the environment. It is important to also note that shelter must afford its occupants comfort and well-being. The authors explained that there has recently been awareness on the part of building professionals about climate change and increase in the understanding of environmental awareness issues relating to energy use in buildings and their ability in ensuring that energy is used efficiently within them. This has led to building professionals thinking outside the box towards finding better and creative ways of addressing the issue of greenhouse gas emissions from buildings into the environment.

In trying to provide an understanding of the meaning of energy use and efficiency in a building, [7] argued that it is the amount of energy used in heating, ventilation and lighting measured in the unit of measurement that conforms with laid down standards for such buildings at every point in time. [37] advanced that energy efficiency improvements are thought to have the potential to support economic growth and social development, while improving occupant health and well-being, as well as enhancing competitiveness and investment opportunities. [24] shed more light on this. The authors noted that with the rate at which the climate around the world is changing, the need has arisen where countries are beginning to change their perceptions about energy use and the way fossil based energy is beginning to harm the environment. According to the authors, buildings worldwide are the major culprits that account for one-third of the greenhouse gases that are released into the environment. [23] explained that the global community in trying to proffer solutions towards arresting the effects of global climate change have started insisting on efforts at standardising solutions that make it mandatory for buildings to be more energy efficient. It was stated that buildings contribute one-third of global $\mathrm{CO}_{2}$ emissions.

The United State (US) Department Office for Energy Efficiency and Renewable Energy (2008) defined an energy efficient building as one that reduces the huge maintenance and utility costs, while also improving the buildings durability. Such buildings are also able to reduce noise levels from the immediate surroundings, while at the same time increasing its comfort level and creating a healthy and safer indoor environment. The main objective and goal of an energy efficient building is to limit further damages within the ecosystem and to reduce the use of natural resources like energy, land, water and other depletable materials within the building's immediate surroundings. The department further noted that reducing energy efficiency in buildings should be the key cardinal point of any country, since this will help in reducing little or no greenhouse gas emissions, the primary cause of global warming. Energy efficiency strategies can be integrated within buildings at project inception or while renovating older and existing buildings.

In order to ensure that buildings become more energy efficient, Architects and other construction professionals have a wide range of materials available in the market they can use in making energy efficiency in buildings a reality. [11] observed that energy efficient design strategies in office buildings have become paramount for several reasons which include the enforcement of building codes and company policies that insist on protecting the 
environment. Other reasons are regulations formulated by local planning authorities, resources management, utility and its associated incentives, reduction in electricity and energy usage, and office buildings comfort and satisfaction. According to [13], from the foregoing, it is evident that there is a consensus among authors that energy efficiency simply means using less energy or minimal amount of energy to achieve optimal result. As a result, an energy efficient building places importance on users' comfort which also conforms to Universal Design principles. [34] have defined Universal Design as a design concept whose main aim is to cater for every person regardless of their abilities at little or no extra cost. The authors further believe that Universal Design contributes to environmental sustainability which is also one of the major components of energy efficiency in buildings.

\subsection{The Concept of Knowledge}

[8] observed that humans have an insatiable quest for knowledge and they can go to any length to acquire and satisfy this innate search for knowledge. The authors further defined knowledge as that of justified true belief. To buttress their position of the definition of knowledge, the authors highlighted that it comprises of three basic attributes that are usually called the tripartite account of knowledge. First and foremost is a situation where the knowledge has a truth contained within it. Secondly, for more understanding of knowledge, there must be a belief condition. This means that a person acquiring a true knowledge must believe it to be true. And lastly, to prove that knowledge is true, it has to be justified. The researchers further argued that knowledge comprises of three basic types: knowledge acquired from experience, knowledge acquired through skills and knowledge acquired through claims.

In addition, [8] observed that experiential knowledge is obtained from man's direct interactions with his immediate environment through his sensory systems. This is then processed by man's mental capacity through observations. Experiential knowledge is said to be personal and only received by directly interfacing with our sensory systems. It is mostly based on perception and reflection. On the other hand, skills knowledge they said is the knowledge about getting things and activities done. Therefore, skills knowledge should also be based on personal experience which is higher than experiential knowledge. This type of knowledge is obtained from performing a series of tasks and learning from them by doing them repeatedly. The last knowledge type is the "know how claim" which is about what is believed to be true.

In relation to this study, knowledge as observed by the authors, is the building industry professionals' knowledge of the various energy efficiency design strategies that are available in building design and construction. It is assumed that having the knowledge and understanding of the availability and applicability of the different types of energy efficiency design strategies by building professionals, is essential for the development of office building designs that are apt for enhancing users comfort via the conservation of energy within them.

\subsection{Energy Efficiency Design Strategies and Long-Term Trends in the field of Energy Efficient Buildings}

[40] observed that it is not possible to recommend a one fits all method for ensuring maximum usage of energy within a building. This is as a result of the fact that buildings are not designed to perform the same functions and as such, solutions of energy usage and consumption must also vary. In arriving at a best fit measure, care should be taken to note that there are different life cycles in a building and as such, different energy efficiency solutions should be devised accordingly. The authors also observed that buildings have different life cycles with the first being the pre-building phase. At the pre-building phase, the energy efficiency strategies available are: appropriate site selection, better site planning, robust building forms, adequate space planning, effective building envelope selection and the selection of materials of construction that consume less energy. As a result, [33] are of the opinion that retrofitting is one of the most suitable and promising building envelope solutions to reduce the energy consumption in buildings and a very helpful tool to create and maintain thermal comfort in buildings. Others include: appropriate landscaping design that encourages energy efficiency and adequate building materials for construction. It is also important to consider that the manufacturing of construction materials is environmentally friendly, while transporting them to construction sites.

The second building life cycle is referred to as the building phase where the building is constructed and ready for usage. [40] identified methods for energy efficiency in buildings at this phase to include techniques that rely less on energy usage, such as using equipment that consume less energy during the construction process. This also has to do with the specification document usually provided by the architect during construction of a building. The third is the post-building phase, which is the stage where the constructed building needs to be demolished after fulfilling the purpose for which it was constructed. The materials of construction will need to be recycled and eventually, the building, destroyed. Also at this phase, specifications of the methods of demolition are very important, since this has to be effectively coordinated by the Architect and Engineers to ensure effective demolition of the building. The authors made a strong case that at this phase, it is important to note that building materials need to be recycled. Recyclable building components should be separated to enhance raw materials protection for building materials to be reproduced. Fewer machines and equipment need to be 
used while the demolition process is in progress.

In a study conducted in Belgium on the impact of control rules on the efficiency of shading devices and free cooling for office buildings, [38] observed that the designers' task must include control systems design in order to build high comfort low energy buildings. Further to this, [31] in their study in the United Kingdom on the effects of open windows on thermal comfort and energy use in buildings observed that understanding occupant behaviours within office buildings was very important in the prediction of operational energy use in buildings. Another study of importance in understanding energy efficiency in office buildings was that conducted by [22] also in the United Kingdom on cool roof technologies in London where it was observed that applying cool roof technology was beneficial in terms of increased thermal comfort in the summer and decreases overall energy use for heating and cooling within office buildings. [39] further conducted a study in Singapore on the thermal benefits of city parks within the surroundings of office buildings and observed that more concern should be paid on reservation of green areas in cities rather than simply replacing them with buildings. [18] carried out a study on the energy efficiency situation in Ghana and reported that near success in energy efficiency in office buildings had been achieved in Ghana by the use of energy efficient lighting initiatives that had been initiated in the Ghanaian construction industry.

[9] in a study conducted in America on operable windows, control and occupant comfort in office buildings revealed that it is critical that office buildings be designed so that occupants can be active participants in the indoor climate feedback loop. [35] in a study on passive building energy savings conducted in America observed that passive energy efficiency strategies are highly sensitive to meteorological factors and, therefore, require a broader understanding of the climatic factors by a designer. [32] also conducted a study in Turkey on improving energy efficiency through the design of the building envelope also observed that design of building envelope can significantly help achieve the heating and cooling objectives and improve energy efficiencies in office buildings. It has also been observed that hybrid shading systems have exhibited noticeable progress over the current decade.

[10] in a study conducted in Singapore on achieving better energy-efficient air conditioning on a review of technologies and strategies further observed that implementation of new technologies and strategies will reduce the energy cost associated with operating air conditioning and the negative environmental impact on office buildings. [15] also conducted a study in America on health and productivity gains from better indoor environments and their relationship with building energy efficiency. The author concluded that theoretical and limited empirical evidence indicates that existing technologies and procedures can improve indoor environments and improve workers' performance in office buildings thereby enhancing users comfort.

\section{Research Methods}

The data used in this article were drawn from a bigger unpublished research project aimed at investigating the implementation of energy efficiency design strategies and integration of energy efficiency design features in office buildings. The research is therefore a pivot study to examine some key issues at close range. As the study was out to investigate the extent to which building professional firms are aware and implement the various energy efficiency design strategies available, the study adopted a quantitative research approach to conduct the research. This method was considered apt to carry out the research due to the large number of respondents involved. As earlier explained in the last paragraph of the introduction, the firms used for the study are those involved in both architecture and engineering design of office buildings situated within the central business district in Abuja, Nigeria. The engineering services focused on are structural, mechanical, electrical and civil. Based on the selection criteria set, sixteen firms were found to satisfy the requirements. The sixteen firms constituted the sample size of firms. The firms are those that carry out architecture and the four engineering services previously itemised. Each of the sixteen firms provided five respondents of the senior cadre to answer the survey questions. Those that participated in each firm are: an architect, a structural engineer, a mechanical engineer, an electrical engineer and a civil engineer. Consequently, the sample size of building professionals used for the study is 80 .

A structured questionnaire (survey instrument) specifically designed for the study was used to gather primary field data from the participants. The survey instrument was designed with three sections. The first section was used to gather the respondents' bio-data. The second was employed to collect data on the awareness level of the firms on energy efficiency design strategies available for use in office buildings. The participants were asked to indicate their level of knowledge of the energy efficiency design strategies presented to them which was identified in previous literatures. A 5-point Likert type scale ranging from 1-5 was used to measure their awareness level, with 1 representing No Knowledge, 2-Little Knowledge, 3-Moderate Knowledge, 4-High Knowledge and 5-Very High Knowledge. The third section was used to gather data on the extent to which the firms have implemented the energy efficiency design strategies in office building designs. A 5-point Likert type scale similar to the one employed in the second section was also used. The survey was administered between February and June 2020. In total, 80 copies of the questionnaire were administered and all were retrieved and useful. The Statistical Package for Social Sciences (SPSS) software was used to analyse the 
data obtained from the survey. Due to the nature of the research questions, the principal type of analysis the data were subjected to was descriptive statistics which involved the calculation of percentages and frequency distribution. The results were presented with the aid of tables and charts for easy understanding.

\section{Results and Discussion}

\subsection{Profiles of Respondents}

A total of 80 hardcopies of the questionnaires were administered to building professionals of selected firms that constitute the sample size as earlier explained in the research methods section. All the survey instruments were retrieved to represent $100 \%$ retrieval rate. All the retrieved survey instruments were found useful and analysed. Table
1 shows relevant personal profiles of the participants.

The data in Table 1 indicate that majority $(86.20 \%)$ of the participants are males, while few $(13.80 \%)$ are females. Most (66.30\%) of the professionals are between 36 and 55 years of age and majority $(63.90 \%)$ of them had professional experience spanning between 6 to 20 years. Just few $(22.80 \%)$, had more than 20 years of professional experience. Majority $(80.00 \%)$ of the respondents are working in Engineering firms, few $(20.00 \%)$ engaged in Architectural firms and another few $(20.00 \%)$ playing the role of Civil, Mechanical, Electrical and Structural Engineers and Architects in their respective organisations. These results indicate that the professionals who participated in the study are mainly middle-aged male Engineers and Architects with professional experience of over 5 years. Such category of experts is considered qualified enough to provide valid data for the study.

Table 1. Profiles of the Building Professionals

\begin{tabular}{|c|c|c|c|c|}
\hline SN & Respondents Characteristics & Categories & $\begin{array}{c}\text { Frequency } \\
(\mathbf{n}=\mathbf{8 0})\end{array}$ & $\begin{array}{c}\text { Percentage } \\
100 \%\end{array}$ \\
\hline \multirow{2}{*}{1} & \multirow{2}{*}{ Gender } & Male & 69 & 86.20 \\
\hline & & Female & 11 & 13.80 \\
\hline \multirow{6}{*}{2} & \multirow{6}{*}{ Age Grouping in Years } & 25 & 11 & 13.80 \\
\hline & & $26-35$ & 14 & 17.50 \\
\hline & & $36-45$ & 33 & 41.30 \\
\hline & & $46-55$ & 20 & 25.00 \\
\hline & & $55-65$ & 1 & 1.20 \\
\hline & & More than 65 years & 1 & 1.20 \\
\hline \multirow{3}{*}{3} & \multirow{3}{*}{ Highest Educational Qualification } & Diploma & 7 & 8.70 \\
\hline & & Bachelor degree & 21 & 26.30 \\
\hline & & Master degree & 52 & 65.00 \\
\hline \multirow{5}{*}{4} & \multirow{5}{*}{ Role in the Firm } & Architect & 16 & 20.00 \\
\hline & & Civil Engineer & 16 & 20.00 \\
\hline & & Mechanical Engineer & 16 & 20.00 \\
\hline & & Electrical Engineer & 16 & 20.00 \\
\hline & & Structural Engineer & 16 & 20.00 \\
\hline \multirow{6}{*}{5} & \multirow{6}{*}{$\begin{array}{l}\text { Years of Professional Working } \\
\text { Experience }\end{array}$} & $1-5$ & 11 & 13.80 \\
\hline & & $6-10$ & 27 & 33.80 \\
\hline & & $11-15$ & 19 & 23.80 \\
\hline & & $15-20$ & 5 & 6.30 \\
\hline & & $21-25$ & 9 & 11.30 \\
\hline & & More than 25 years & 9 & 11.50 \\
\hline \multirow{5}{*}{6} & \multirow{5}{*}{ Type of Firm Employed in } & Architectural Firm & 16 & 20.00 \\
\hline & & Civil Engineering Firm & 16 & 20.00 \\
\hline & & $\begin{array}{l}\text { Mechanical Engineering } \\
\text { Firm }\end{array}$ & 16 & 20.00 \\
\hline & & Electrical Engineering Firm & 16 & 20.00 \\
\hline & & Structural Engineering Firm & 16 & 20.00 \\
\hline
\end{tabular}


4.2. Awareness Level of the Firms on Energy Efficiency Design Strategies Employed in Office Buildings

This section is a presentation of the results on the level of awareness of the participating firms on known energy efficiency design strategies employed in office buildings. 29 Energy efficiency design strategies identified in Literature were used for this purpose. Table 2 shows the results of the descriptive statistics carried out.

Table 2. Descriptive Statistics on Awareness Level of the Firms on Energy Efficiency Design Strategies Employed in Office Buildings

\begin{tabular}{|c|c|c|c|c|c|c|c|c|c|}
\hline \multirow[b]{2}{*}{ SN } & \multirow{2}{*}{$\begin{array}{c}\text { Energy } \\
\text { Efficiency } \\
\text { Design } \\
\text { Strategies }\end{array}$} & \multicolumn{5}{|c|}{$\begin{array}{c}\text { Awareness Level } \\
(\mathrm{N}=80)\end{array}$} & \multirow[b]{2}{*}{ Mean } & \multirow[b]{2}{*}{$\begin{array}{c}\text { Std. } \\
\text { Deviation }\end{array}$} & \multirow[b]{2}{*}{ Ranking } \\
\hline & & $\begin{array}{l}\text { No (1) } \\
\text { n(\%) }\end{array}$ & $\begin{array}{l}\text { Little (2) } \\
\text { n(\%) }\end{array}$ & $\begin{array}{c}\text { Moderate } \\
(\mathbf{3}) \\
\text { n(\%) }\end{array}$ & $\begin{array}{c}\text { High (4) } \\
\text { n(\%) }\end{array}$ & $\begin{array}{c}\text { Very High } \\
(5) \\
\text { n(\%) }\end{array}$ & & & \\
\hline 1 & Site Planning & $2(2.50)$ & $5(6.30)$ & $19(23.80)$ & $36(45.00)$ & $18(22.50)$ & 3.78 & .950 & \multirow{2}{*}{ 1st } \\
\hline 2 & $\begin{array}{c}\text { Natural } \\
\text { Ventilation }\end{array}$ & $3(3.80)$ & $4(5.00)$ & $25(31.30)$ & $23(28.80)$ & $25(31.30)$ & 3.78 & 1.06 & \\
\hline 3 & $\begin{array}{c}\text { Building } \\
\text { Orientation }\end{array}$ & $1(1.30)$ & $3(3.80)$ & $30(37.50)$ & $25(31.30)$ & $21(26.30)$ & 3.77 & .927 & \multirow[t]{2}{*}{$3^{\text {rd }}$} \\
\hline 4 & $\begin{array}{c}\text { Space } \\
\text { Organisation }\end{array}$ & $0(0.00)$ & $4(5.00)$ & $31(38.80)$ & $24(30.00)$ & $21(26.30)$ & 3.77 & .899 & \\
\hline 5 & Day lighting & $0(0.00)$ & $3(3.80)$ & $32(40.00)$ & $31(38.80)$ & $14(17.50)$ & 3.70 & .801 & $5^{\text {th }}$ \\
\hline 6 & $\begin{array}{l}\text { Window Shape } \\
\text { and Position }\end{array}$ & $1(1.30)$ & $8(10.00)$ & $28(35.00)$ & $28(35.00)$ & $15(18.80)$ & 3.60 & .949 & $6^{\text {th }}$ \\
\hline 7 & Building Form & $0(0.00)$ & $13(16.30)$ & $23(28.80)$ & $31(38.80)$ & $13(16.30)$ & 3.55 & .953 & \multirow{2}{*}{$7^{\text {th }}$} \\
\hline 8 & Site Selection & $1(1.30)$ & $4(5.00)$ & $34(42.50)$ & $32(40.00)$ & $9(11.30)$ & 3.55 & .809 & \\
\hline 9 & $\begin{array}{l}\text { Building } \\
\text { Materials }\end{array}$ & $1(1.30)$ & $4(5.00)$ & $32(40.00)$ & $37(46.30)$ & $6(7.50)$ & 3.53 & .762 & $9^{\text {th }}$ \\
\hline 10 & Building Shape & $0(0.00)$ & $6(7.50)$ & $42(52.50)$ & $16(20.00)$ & $16(20.00)$ & 3.52 & .899 & $10^{\text {th }}$ \\
\hline 11 & $\begin{array}{c}\text { Integrated } \\
\text { Design Process }\end{array}$ & $5(6.30)$ & $6(7.50)$ & $24(30.00)$ & $40(50.00)$ & $5(6.30)$ & 3.42 & .951 & $11^{\mathrm{h}}$ \\
\hline 12 & $\begin{array}{l}\text { Building } \\
\text { Envelope }\end{array}$ & $5(6.30)$ & $13(16.30)$ & $21(26.30)$ & $31(38.80)$ & $10(12.50)$ & 3.35 & 1.09 & \multirow{2}{*}{$12^{\text {th }}$} \\
\hline 13 & $\begin{array}{l}\text { Landscape } \\
\text { Design }\end{array}$ & $0(0.00)$ & $19(23.80)$ & $24(30.00)$ & $27(33.80)$ & $10(12.50)$ & 3.35 & .982 & \\
\hline 14 & $\begin{array}{c}\text { Exterior } \\
\text { Shading Design }\end{array}$ & $6(7.50)$ & $7(8.80)$ & $30(37.50)$ & $28(35.00)$ & $9(11.30)$ & 3.33 & 1.04 & $14^{\text {th }}$ \\
\hline 15 & $\begin{array}{c}\text { Renewable } \\
\text { Energy Sources }\end{array}$ & $2(2.50)$ & $10(12.50)$ & $40(50.00)$ & $18(22.50)$ & $10(12.50)$ & 3.30 & .933 & $15^{\text {th }}$ \\
\hline 16 & $\begin{array}{c}\text { Bright External } \\
\text { Paints }\end{array}$ & $4(5.00)$ & $19(23.80)$ & $13(16.30)$ & $39(48.80)$ & $5(6.30)$ & 3.27 & 1.05 & $16^{\text {th }}$ \\
\hline 17 & $\begin{array}{l}\text { Mixed Mode } \\
\text { Ventilation } \\
\text { Systems }\end{array}$ & $1(1.30)$ & $16(20.00)$ & $40(50.00)$ & $15(18.80)$ & $8(10.80)$ & 3.16 & .906 & $17^{\text {th }}$ \\
\hline 18 & $\begin{array}{l}\text { Day lighting } \\
\text { Control } \\
\text { Mechanisms }\end{array}$ & $2(2.50)$ & $16(20.00)$ & $41(51.30)$ & $12(15.00)$ & $9(11.30)$ & 3.12 & .946 & \multirow[t]{2}{*}{$18^{\text {th }}$} \\
\hline 19 & $\begin{array}{l}\text { Biophilic } \\
\text { Design }\end{array}$ & $2(2.50)$ & $28(35.00)$ & $14(17.50)$ & $30(37.50)$ & $6(7.50)$ & 3.12 & 1.05 & \\
\hline 20 & $\begin{array}{c}\text { Night } \\
\text { Ventilation }\end{array}$ & $2(2.50)$ & $30(37.50)$ & $18(22.50)$ & $23(28.80)$ & $7(8.80)$ & 3.03 & 1.06 & \multirow[t]{2}{*}{$20^{\text {th }}$} \\
\hline 21 & Green Roofs & $7(8.80)$ & $16(20.00)$ & $29(36.30)$ & $23(28.80)$ & $5(6.30)$ & 3.03 & 1.04 & \\
\hline 22 & $\begin{array}{c}\text { Future Retrofit } \\
\text { Design }\end{array}$ & $5(6.30)$ & $17(21.30)$ & $33(41.30)$ & $21(26.30)$ & $4(5.00)$ & 3.02 & .967 & $22^{\text {nd }}$ \\
\hline 23 & $\begin{array}{l}\text { Solar Hot } \\
\text { Water }\end{array}$ & $1(1.30)$ & $24(30.00)$ & $34(42.50)$ & $15(18.80)$ & $6(7.50)$ & 3.01 & .920 & \multirow{2}{*}{$23^{\text {rd }}$} \\
\hline 24 & $\begin{array}{c}\text { Wall to Wall } \\
\text { Ratio }\end{array}$ & $3(3.80)$ & $24(30.00)$ & $24(30.00)$ & $27(33.80)$ & $2(2.50)$ & 3.01 & .947 & \\
\hline 25 & $\begin{array}{c}\text { Bright } \\
\text { Coloured Roofs }\end{array}$ & $4(5.00)$ & $19(23.80)$ & $13(16.30)$ & $39(48.80)$ & $5(6.30)$ & 2.93 & 1.11 & $25^{\text {th }}$ \\
\hline 26 & $\begin{array}{c}\text { Service Core } \\
\text { Placement }\end{array}$ & $\begin{array}{c}9(11.3 \\
0)\end{array}$ & $27(33.80)$ & $19(23.80)$ & $23(28.80)$ & $2(2.50)$ & 2.77 & 1.06 & $26^{\text {th }}$ \\
\hline 27 & $\begin{array}{l}\text { Occupancy } \\
\text { Sensors }\end{array}$ & $\begin{array}{c}8(10.0 \\
0)\end{array}$ & $22(27.50)$ & $35(43.80)$ & $8(10.30)$ & $2(2.50)$ & 2.73 & .937 & $27^{\text {th }}$ \\
\hline 28 & $\begin{array}{l}\text { Bioclimatic } \\
\text { Design }\end{array}$ & $4(5.00)$ & $36(45.00)$ & $27(33.80)$ & $10(12.50)$ & $8(3.80)$ & 2.65 & .901 & $28^{\text {th }}$ \\
\hline 29 & $\begin{array}{l}\text { Eco Feedback } \\
\text { Mechanism }\end{array}$ & $8(3.80)$ & $39(48.80)$ & $24(30.00)$ & $12(15.00)$ & $2(2.50)$ & 2.63 & .875 & $29^{\text {th }}$ \\
\hline
\end{tabular}

$\mathrm{n}=$ frequency; $\%=$ percentage 
The results in Table 2 show that $65.50 \%$ of the professionals have more than moderate level of knowledge of site planning and natural ventilation design strategies, $60.10 \%$ (building orientation), $57.60 \%$ (space organisation) and $56.30 \%$ (day lighting design strategies). The result further shows that in terms of ranking, the professionals are most knowledgeable on site planning and natural ventilation design strategies with each criterion having a mean score of 3.78. These are closely followed by building orientation and space organisation with each having a mean score of 3.77. This is followed by day lighting design strategies whose mean score is 3.70 .

The participants were however found to have a low level of knowledge of specification of bright coloured roofs, service core placement, occupancy sensors, bioclimatic designs and eco feedback mechanism. This informed their low mean values of $2.93,2.77,2.73,2.65$ and 2.63, respectively, as earlier indicated in Table 2. In general, the result indicates that the firms that constitute the sample size of this study are more knowledgeable on site planning and natural ventilation design, building orientation, space organisation and day lighting design than any other energy efficiency design strategy available for deployment in office buildings. The general implication of the findings of the study is that the building design firms practicing in Abuja, Nigeria are not only knowledgeable enough to design office buildings that are energy efficient to a reasonable extent, but are indeed implementing the strategies in the design and development of energy efficient office buildings, to a reasonable extent. This is considered apt towards promoting energy efficient office building development in the study area.

The result in Table 2 is further summarised for clarity and better understanding in the following Figure 1.

Generally, majority $(34.46 \%)$ of the participants have moderate knowledge of the various energy efficiency design strategies used in office buildings. Some (31.41\%) have high knowledge and few (11.67\%) have very high knowledge as shown in Figure 1. However, a significant number $(22.49 \%)$ of the respondents have no knowledge at all. These findings indicate that while few of the firms that participated in the survey might have difficulties in the adequate deployment of appropriate energy efficiency design strategies in office buildings, majority of the firms are knowledgeable enough towards producing office building designs that are energy efficient. This is because most of the firms are aware about the existence of the various energy efficiency design strategies that was investigated.

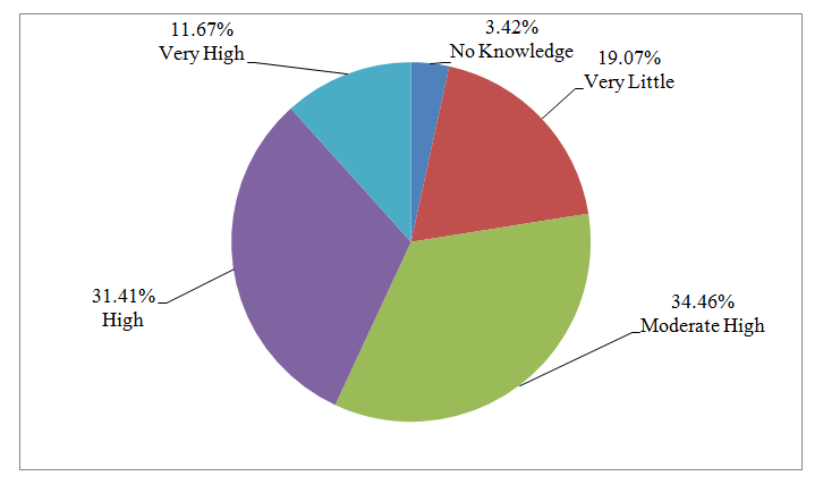

Figure 1. Summary of the Awareness Level of the Firms on Energy Efficiency Design Strategies Employed in Office Buildings

\subsection{Implementation Level of the Firms of Energy Efficiency Design Strategies in Office Buildings}

This section presents the results on the extent to which professionals in the architectural and engineering firms investigated, have implemented the various energy efficiency design strategies in office buildings they have designed. The result of the descriptive analysis conducted in this regard is presented in Table 3. 
Table 3. Descriptive Statistics on Implementation Level of the Firms of Energy Efficiency Design Strategies in Office Buildings

\begin{tabular}{|c|c|c|c|c|c|c|c|c|c|}
\hline \multirow[b]{2}{*}{ SN } & \multirow[b]{2}{*}{$\begin{array}{l}\text { Energy Efficiency } \\
\text { Design Strategies }\end{array}$} & \multicolumn{5}{|c|}{$\begin{array}{c}\text { Implementation Level } \\
(\mathbf{N}=\mathbf{8 0})\end{array}$} & \multirow[b]{2}{*}{ Mean } & \multirow[b]{2}{*}{$\begin{array}{c}\text { Std. } \\
\text { Deviation }\end{array}$} & \multirow[b]{2}{*}{ Ranking } \\
\hline & & $\begin{array}{c}\text { None } \\
(1) \\
\text { n(\%) }\end{array}$ & $\begin{array}{c}\text { Little } \\
(2) \\
\text { n(\%) }\end{array}$ & $\begin{array}{c}\text { Moderate } \\
\text { (3) } \\
\text { n(\%) }\end{array}$ & $\begin{array}{c}\text { High } \\
(4) \\
n(\%)\end{array}$ & $\begin{array}{c}\text { Very } \\
\text { High } \\
(5) \\
\text { n(\%) }\end{array}$ & & & \\
\hline 1 & $\begin{array}{l}\text { Building Plan } \\
\text { and Space } \\
\text { Organisation }\end{array}$ & $2(2.50)$ & $4(5.00)$ & $16(20.00)$ & $19(23.80)$ & $39(48.80)$ & 4.11 & 1.05 & $1^{\text {st }}$ \\
\hline 2 & Site Planning & $2(2.50)$ & $11(13.80)$ & $11(13.80)$ & $21(26.30)$ & $35(43.80)$ & 3.95 & 1.16 & $2^{\text {nd }}$ \\
\hline 3 & $\begin{array}{l}\text { Building } \\
\text { Orientation }\end{array}$ & $3(3.80)$ & 11(13.80) & 11(13.80) & $23(28.80)$ & $34(42.50)$ & 3.92 & 1.19 & $3^{\text {rd }}$ \\
\hline 4 & $\begin{array}{c}\text { Natural } \\
\text { Ventilation } \\
\text { Design } \\
\end{array}$ & $2(2.50)$ & 11(13.80) & $17(21.30)$ & $19(23.80)$ & $31(38.80)$ & 3.82 & 1.16 & $4^{\text {th }}$ \\
\hline 5 & Building Shape & $2(2.50)$ & $8(10.00)$ & $19(23.80)$ & $40(50.00)$ & $11(13.80)$ & 3.62 & 0.93 & $5^{\text {th }}$ \\
\hline 6 & Building Form & $3(3.80)$ & $7(8.80)$ & $16(20.00)$ & $46(57.50)$ & $8(10.00)$ & 3.61 & 0.92 & $6^{\text {th }}$ \\
\hline 7 & Day Lighting & $3(3.80)$ & $12(15.00)$ & $15(18.80)$ & $35(43.80)$ & $15(18.80)$ & 3.58 & 1.07 & $7^{\text {th }}$ \\
\hline 8 & $\begin{array}{l}\text { Building } \\
\text { Envelope }\end{array}$ & $4(5.00)$ & $10(12.50)$ & $16(20.00)$ & $42(52.50)$ & $8(10.00)$ & 3.50 & 1.00 & $8^{\text {th }}$ \\
\hline 9 & $\begin{array}{c}\text { Integrated Design } \\
\text { Process }\end{array}$ & $9(11.30)$ & $6(7.50)$ & $10(12.50)$ & $47(58.80)$ & $8(10.00)$ & 3.48 & 1.13 & $9^{\text {th }}$ \\
\hline 10 & $\begin{array}{c}\text { Day lighting } \\
\text { Control } \\
\text { Mechanisms } \\
\end{array}$ & $5(6.30)$ & $(16.30)$ & $16(20.00)$ & $39(48.80)$ & $7(8.80)$ & 3.37 & 1.05 & $10^{\text {th }}$ \\
\hline 11 & $\begin{array}{c}\text { Exterior Shading } \\
\text { Design }\end{array}$ & $5(6.30)$ & $8(10.00)$ & $24(30.00)$ & $39(48.80)$ & $4(5.00)$ & 3.36 & 0.95 & \\
\hline 12 & $\begin{array}{c}\text { Building } \\
\text { Materials } \\
\end{array}$ & $3(3.80)$ & $9(11.30)$ & $0(0.00)$ & $28(35.00)$ & $8(10.00)$ & 3.36 & 0.94 & $11^{\text {th }}$ \\
\hline 13 & $\begin{array}{l}\text { Window Shape } \\
\text { and Position }\end{array}$ & $10(12.50)$ & $8(10.00)$ & $12(15.00)$ & $43(53.80)$ & $7(8.80)$ & 3.36 & 1.17 & \\
\hline 14 & $\begin{array}{l}\text { Design for Future } \\
\text { Retrofits }\end{array}$ & $5(6.30)$ & (18.80) & $15(18.80)$ & $38(47.50)$ & $7(8.80)$ & 3.33 & 1.07 & $14^{\text {th }}$ \\
\hline 15 & Site Selection & $11(14.80)$ & $11(13.80)$ & $7(9.90)$ & $39(49.40)$ & $9(12.30)$ & 3.30 & 1.28 & $15^{\text {th }}$ \\
\hline 16 & $\begin{array}{l}\text { Landscape } \\
\text { Design }\end{array}$ & $7(8.80)$ & $8(10.00)$ & $35(43.80)$ & $20(25.00)$ & $10(12.50)$ & 3.22 & 1.07 & $16^{\text {th }}$ \\
\hline 17 & $\begin{array}{c}\text { Mixed Mode } \\
\text { Ventilation } \\
\text { Systems } \\
\end{array}$ & $4(5.00)$ & $11(13.80)$ & $41(51.30)$ & $16(20.00)$ & $8(10.00)$ & 3.16 & 0.96 & $17^{\text {th }}$ \\
\hline 18 & $\begin{array}{c}\text { Service Core } \\
\text { Placement }\end{array}$ & $8(10.00)$ & $18(22.50)$ & $14(17.50)$ & $36(45.00)$ & $\mathrm{n}(5.00)$ & 3.12 & 1.12 & $18^{\text {th }}$ \\
\hline 19 & $\begin{array}{c}\text { Provision for } \\
\text { Renewable } \\
\text { Energy Sources }\end{array}$ & $9(11.30)$ & $8(10.00)$ & $39(48.80)$ & $17(21.30)$ & $7(8.80)$ & 3.06 & 1.05 & $19^{\text {th }}$ \\
\hline 20 & $\begin{array}{c}\text { Bright Coloured } \\
\text { Roofs }\end{array}$ & $7(8.80)$ & $19(23.80)$ & $37(46.30)$ & $13(16.30)$ & $4(5.00)$ & 2.85 & 0.96 & $20^{\text {th }}$ \\
\hline 21 & Biophilic Design & $2(2.50)$ & $44(55.50)$ & $17(21.30)$ & $7(8.80)$ & $10(12.50)$ & 2.73 & 1.08 & $21^{\text {st }}$ \\
\hline 22 & $\begin{array}{c}\text { Bright Coloured } \\
\text { External Wall } \\
\text { Paints } \\
\end{array}$ & $7(8.80)$ & $38(47.50)$ & $14(17.50)$ & $13(16.30)$ & $8(10.0) 0$ & 2.71 & 1.14 & $22^{\text {nd }}$ \\
\hline 23 & $\begin{array}{c}\text { Effective Wall to } \\
\text { Wall Ratio }\end{array}$ & $4(5.00)$ & $42(52.50)$ & $15(18.80)$ & $12(15.00)$ & $7(8.80)$ & 2.70 & 1.07 & $23^{\text {rd }}$ \\
\hline 24 & Night Ventilation & $3(3.80)$ & $45(56.30)$ & $15(18.80)$ & $10(12.50)$ & $7(8.80)$ & 2.66 & 1.04 & $24^{\text {th }}$ \\
\hline 25 & $\begin{array}{l}\text { Carbon dioxide } \\
\text { Sensors }\end{array}$ & $5(6.30)$ & $41(51.30)$ & $20(25.00)$ & $8(10.00)$ & $6(7.50)$ & 2.61 & 1.01 & $25^{\text {th }}$ \\
\hline 26 & $\begin{array}{c}\text { Bioclimatic } \\
\text { Design }\end{array}$ & $5(6.30)$ & $45(56.30)$ & $14(17.50)$ & $12(15.00)$ & $4(5.00)$ & 2.56 & 0.99 & $26^{\text {th }}$ \\
\hline 27 & Solar Hot Water & $39(48.80)$ & $9(11.30)$ & $15(18.80)$ & $11(13.80)$ & $6(7.50)$ & 2.20 & 1.37 & $27^{\text {th }}$ \\
\hline 28 & $\begin{array}{l}\text { Eco- Feedback } \\
\text { Systems }\end{array}$ & $36(45.00)$ & $11(13.80)$ & $18(22.50)$ & $13(16.30)$ & $2(2.50)$ & 2.17 & 1.24 & $28^{\text {th }}$ \\
\hline 29 & Green Roofs & $40(50.00)$ & $14(17.50)$ & $16(20.00)$ & $7(8.80)$ & $3(3.80)$ & 1.98 & 1.18 & $29^{\text {th }}$ \\
\hline
\end{tabular}

$\mathrm{n}=$ frequency, $\%=$ percentage 
Table 3 shows that in terms of ranking, the professionals mostly implemented building plan and space organisation and site planning design strategies which have mean scores of 4.11 and 3.95 respectively. This is followed by building orientation with mean score of 3.92 , natural ventilation design (3.82) and building shape design (3.62). The result also shows that most of the professionals have more than moderately implemented building plan and space organisation, site planning, building orientation and natural ventilation design strategies considering their scores of $72.60 \%, 70.10 \%, 71.30 \%$ and $62.60 \%$ respectively.

However, the firms' implementation of carbon dioxide sensors, bioclimatic design, solar hot water, eco-feedback mechanisms and green roofs were found to be low, with mean scores of 2.61, 2.56, 2.20, 2.17 and 1.98 respectively. The results further indicate that the firms that constitute the sample size have mostly implemented building plan and space organisation, site planning and building orientation, natural ventilation design strategies, building shape and building form than any other energy efficiency design strategies in office buildings designed by them. This implies that the firms are implementing energy efficiency design strategies in the development of office buildings to a reasonable extent in the study area.

Figure 2 provides a summary of the result on the extent to which the building professional firms implemented energy efficiency design strategies in office buildings they have designed.

The descriptive analysis in Figure 2 shows that most $(31.60 \%)$ of the firms have moderately implemented energy efficiency design strategies. Some $(20.88 \%)$ have highly implemented them, whereas, few $(16.54 \%)$ have very highly implemented them. However, a significant percentage $(30.96 \%)$ has never implemented any energy efficiency design strategy in any office building design. The result also indicates that most of the firms that participated in the research have implemented the different energy efficiency design strategies investigated in this study. This implies that majority of the firms are promoting the development of energy efficient office buildings through their designs in the study area.

\subsection{Discussion}

Generally, Nigeria is faced with some challenges with regards to realising improvements in energy efficiency in buildings. According to the 2016 Building Energy Efficiency Guideline of Nigeria, some of the major barriers towards realising improvements in energy efficiency in buildings are first and foremost, lack of awareness and information on the benefits of energy efficiency measures in buildings. The second is inadequate policy, legal and regulatory frameworks. The third is lack of technical expertise. And the last is lack of showcased energy efficiency buildings to learn and draw inspiration from. It is as a result of lack of showcased energy efficient buildings that this study was conceived to fill the gap, towards promoting the importance of energy efficiency in office buildings in the study area. Though findings from [4] indicated that the knowledge of energy efficiency design strategies among construction professionals in Nigeria is low. This aligns with similar studies in China [12]; Malaysia [5]; and New York, Sydney and Tokyo [36]. However, this finding contradicts the results from this study. The result indicated that the knowledge of energy efficiency design strategies is good among relevant building professional firms in the Nigerian design and construction industry.

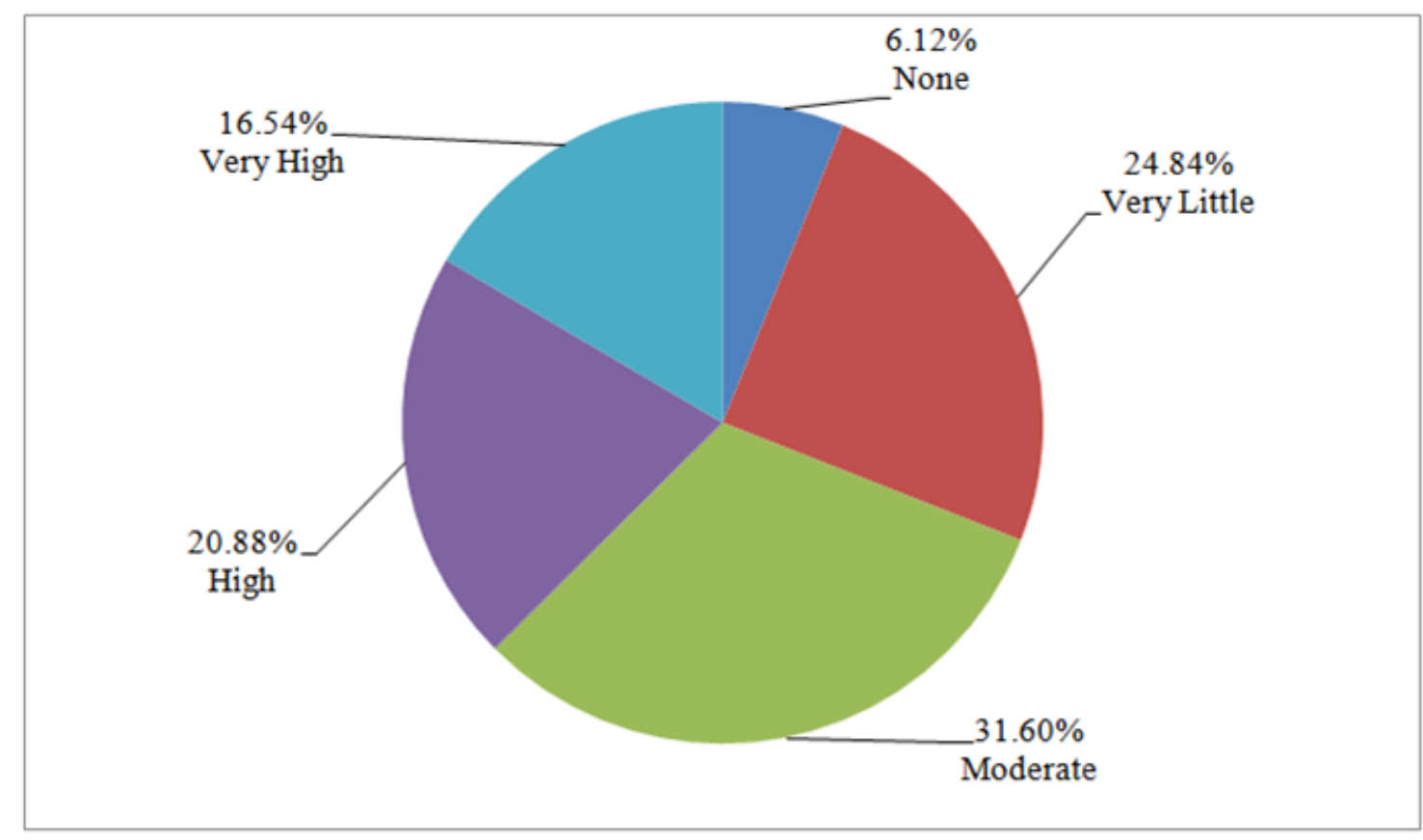

Figure 2. Summary of the Implementation Level of the Firms on Energy Efficiency Design Strategies in Office Buildings 


\section{Conclusions}

The study investigated the awareness and implementation levels of building professional firms of energy efficiency design strategies available for deployment in office buildings in Abuja, Nigeria. This was done in order to ascertain the current level of knowledge and implementation of the strategies within the building industry in the study area. The study investigation was based on 29 strategies found in previous literatures. The study found that both the awareness and implementation levels of the strategies among 80 participants drawn from 16 firms that constituted the sample size of the study are high and reasonable. While the majority (78\%) of the respondents are knowledgeably informed of the various energy efficiency design strategies available for deployment in office building designs, few (22\%) of them having little or no knowledge of the strategies investigated. The result on implementation level indicated also that most $(69 \%)$ of the participants recorded a high rate, whereas, few $(31 \%)$ recorded a low rate. The study also uncovered the strategies the firms are mostly aware of as: site planning, natural ventilation and building orientation. Whereas, the strategies they mostly implement are: building plan and space organisation, site planning and building orientation. The general implication of the findings is that majority of the building professional firms situated in Abuja, Nigeria, have what it takes in terms of adequate knowledge, towards the deployment of energy efficiency design strategies in the development of office buildings.

The study contributed to knowledge by providing information on the knowledge base and implementation level of building professional firms in Abuja, Nigeria on energy efficiency design strategies available for deployment in office buildings. It also uncovered the strategies the firms are mostly aware of, as well as the most commonly implemented of the strategies in the study area. Based on the findings, it is recommended that in order to maintain the high level of understanding and deployment of the different energy efficiency design strategies among the building professionals in the study area, relevant stakeholders in the building industry in the country, should provide platforms from time to time for promoting the benefits of energy efficiency design strategies in the country. This calls for awareness programmes on energy efficiency design strategies practices by professional associations in the Nigerian building industry such as, the Nigerian Institute of Architects (NIA) and the Nigerian Society of Engineers (NSE).

The authors recognise that the scope of the study that is limited to building professional firms opinion in Abuja, Nigeria constitute a limitation for the study. To this end, similar studies can be conducted using a wider scope that will include more states or cover different geographical areas in the country. Such studies can also be extended to other parts of the globe. Also, the result of the study was based on the opinion of building professionals and not on what obtains in existing office building developments. To this end, further studies can be conducted to investigate the extent, to which the various energy efficiency design strategies available, are implemented in existing office buildings. Though the study investigation was limited to a geographical location in Nigeria, the research contains useful resource materials for other researchers to benefit from on a global level. In general, the research can perform as a starting point for creating a new platform of research for future qualitative and quantitative investigations within the broad image of "energy efficiency in office buildings" worldwide.

\section{Acknowledgments}

The authors acknowledge the efforts of Covenant University Centre for Research, Innovation and Discovery (CUCRID), in driving research in the institution. The authors are also grateful to the management of the institution for providing the funds and other necessary infrastructural facilities relied upon towards conducting the research. The authors further acknowledge the anonymous reviewers whose suggestions contributed in improving the quality of the initial manuscript.

\section{REFERENCES}

[1] Adeyemi, A., Martin, D., Kasim, R., \& Adeyemi, A. I. (2017). Facilities improvement for sustainability of existing public office buildings in Nigeria, ATBU. Journal of Environmental Technology, 10(1), 12-34.

[2] Al-Masrani, S. M., Al-Obaidi, K. M., Zalin, N. A., \& Isma, M. A. (2018). Design optimisation of solar shading systems for tropical office buildings: Challenges and future trends. Solar Energy, 170, 849-872.

[3] Amasuomo, T. T., Atanda, J., \& Baird, G. (2017). Development of a building performance assessment and design tool for residential buildings in Nigeria. Procedia engineering, 180, 221-230.

[4] Atanda, J. O., \& Olukoya, O. A. (2019). Green building standards: Opportunities for Nigeria. Journal of Cleaner Production, 227, 366-377.

[5] Azizi, N. S. M., Wilkinson, S., \& Fassman, E. (2015). Strategies for improving energy saving behaviour in commercial buildings in Malaysia. Engineering, Construction and Architectural Management.

[6] Batagarawa, A., Hamza, N., \& Dudek, S. J. (2011). Disaggregating primary electricity consumption for office buildings in Nigeria. In Proceedings of Building Simulation 2011: 12th Conference of International Building (Vol. 1416).

[7] Baumert, K. A., Pershing, J., \& Herzog, T. (2005). Climate 
Data: A sectoral perspective. Pew Center on Global Climate Change.

[8] Bolisani, E., \& Bratianu, C. (2018). The elusive definition of knowledge. In Emergent Knowledge Strategies (pp. 1-22). Springer, Cham.

[9] Brager, G., Paliaga, G., \& De Dear, R. (2004). Operable windows, personal control and occupant comfort.

[10] Chua, K. J., Chou, S. K., Yang, W. M., \& Yan, J. (2013). Achieving better energy-efficient air conditioning-a review of technologies and strategies. Applied Energy, 104, 87-104.

[11] Day, J. K., \& Gunderson, D. E. (2015). Understanding high performance buildings: The link between occupant knowledge of passive design systems, corresponding behaviors, occupant comfort and environmental satisfaction. Building and Environment, 84, 114-124.

[12] Ding, C., \& Zhou, N. (2020). Using Residential and Office Building Archetypes for Energy Efficiency Building Solutions in an Urban Scale: A China Case Study. Energies, 13(12), 3210.

[13] Erebor, E., Ibem, E., Ezema, I.C., Sholanke, A.B. (2020). International Conference on Energy and Sustainable Environment (ICESE); July 28th-July 30th, 2020.

[14] Ezema, I. C., Olotuah, A. O., \& Fagbenle, O. I. (2016). Evaluation of energy use in public housing in Lagos, Nigeria: Prospects for renewable energy sources. International Journal of Renewable Energy Development, $5(1), 15$

[15] Fisk, W. J. (2000). Health and productivity gains from better indoor environments and their relationship with building energy efficiency. Annual review of energy and the environment, 25(1), 537-566.

[16] Geissler, S., Österreicher, D., \& Macharm, E. (2018). Transition towards energy efficiency: Developing the Nigerian building energy efficiency code. Sustainability, $10(8), 2620$

[17] Griego, D., Krarti, M., \& Hernandez-Guerrero, A. (2015). Energy efficiency optimization of new and existing office buildings in Guanajuato, Mexico. Sustainable Cities and Society, 17, 132-140.

[18] Gyamfi, S., Diawuo, F. A., Kumi, E. N., Sika, F., \& Modjinou, M. (2018). The energy efficiency situation in Ghana. Renewable and Sustainable Energy Reviews, 82, $1415-1423$.

[19] Haruna, H., Wakawa, U. B., Isa, A. A., \& Umar, A. Energy Conscious Design Elements in Office Buildings in Hot-Dry Climatic Region of Nigeria.

[20] Ismail, A. I., Kunle, A. A., \& Ronke, O. Y. 1. Department of Architectural Technology, Osun State Polytechnic, Iree, Nigeria 2. Department of Architecture, Ladoke Akintola University of Technology, Ogbomoso, Nigeria 3. Department of Architecture, BellsTech Ota, Ogun State.

[21] Kozusznik, M. W., Maricutoiu, L. P., Peiró, J. M., Virga, D. M., Soriano, A., \& Mateo-Cecilia, C. (2019). Decoupling office energy efficiency from employees' well-being and performance: A systematic review. Frontiers in psychology,
$10,293$.

[22] Kolokotroni, M., Gowreesunker, B. L., \& Giridharan, R. (2013). Cool roof technology in London: An experimental and modelling study. Energy and Buildings, 67, 658-667.

[23] Li, J., \& Colombier, M. (2009). Managing carbon emissions in China through building energy efficiency. Journal of environmental management, 90(8), 2436-2447.

[24] Li, D. H., Yang, L., \& Lam, J. C. (2013). Zero energy buildings and sustainable development implications-A review. Energy, 54, 1-10.

[25] Lu, Y., Sood, T., Chang, R., \& Liao, L. (2020). Factors impacting integrated design process of net zero energy buildings: an integrate framework. International Journal of Construction Management, 1-13.

[26] Nduka, D. O., \& Ogunsanmi, O. E. (2015). Stakeholders perception of factors determining the adoptability of green building practices in construction projects in Nigeria. Journal of Environment and Earth Science, 5(2), 188-196.

[27] Nigeria Federal Ministry of Power Works and Housing. (2017). Building Energy Efficiency Guideline for Nigeria.

[28] Nwofe, P. A. (2014). Need for energy efficient buildings in Nigeria. International Journal of Energy and Environmental Research, 2(3), 1-9.

[29] Occupational Safety and Health Administration. (2015). Indoor air quality in commercial and institutional buildings. Maroon Ebooks.

[30] Rana, J., Hasan, R., Sobuz, H. R., \& Tam, V. W. (2020). Impact assessment of window to wall ratio on energy consumption of an office building of subtropical monsoon climatic country Bangladesh. International Journal of Construction Management, 1-26.

[31] Rijal, H. B., Tuohy, P., Humphreys, M. A., Nicol, J. F., Samuel, A., \& Clarke, J. (2007). Using results from field surveys to predict the effect of open windows on thermal comfort and energy use in buildings. Energy and buildings, $39(7), 823-836$

[32] Sozer, H. (2010). Improving energy efficiency through the design of the building envelope. Building and environment, 45(12), 2581-2593.

[33] Shandilya, A., Hauer, M., \& Streicher, W. (2020). Optimization of Thermal Behavior and Energy Efficiency of a Residential House Using Energy Retrofitting in Different Climates. Civil Engineering and Architecture, 8(3), pp. 335 - 349. DOI: 10.13189/cea.2020.080318.

[34] Sholanke, A. B., IE, A., \& Gbotosho, J. O. (2020). Compliance of High-rise Buildings Vertical Accessibility Components with Universal Design Strategies: A Case Study of Covenant University, Ota, Nigeria. Civil Engineering and Architecture, 8(5), pp. 735 - 749. DOI: $10.13189 /$ cea.2020.080501

[35] Sadineni, S. B., Madala, S., \& Boehm, R. F. (2011). Passive building energy savings: A review of building envelope components. Renewable and sustainable energy reviews, 15(8), 3617-3631.

[36] Trencher, G., \& Van der Heijden, J. (2019). Instrument interactions and relationships in policy mixes: Achieving 
complementarity in building energy efficiency policies in New York, Sydney and Tokyo. Energy Research \& Social Science, 54, 34-45.

[37] Trotta, G., Spangenberg, J., \& Lorek, S. (2018). Energy efficiency in the residential sector: identification of promising policy instruments and private initiatives among selected European countries. Energy Efficiency, 11(8), 2111-2135.

[38] Van Moeseke, G., Bruyère, I., \& De Herde, A. (2007). Impact of control rules on the efficiency of shading devices and free cooling for office buildings. Building and environment, 42(2), 784-793.

[39] Yu, C., \& Hien, W. N. (2006). Thermal benefits of city parks. Energy and buildings, 38(2), 105-120.

[40] Yüksek, I., \& Karadayi, T. T. (2017). Energy-Efficient Building Design in the Context of Building Life Cycle. In Energy Efficient Buildings. IntechOpen.

[41] Zeng, R., Chini, A., Srinivasan, R. S., \& Jiang, P. (2017). Energy efficiency of smart windows made of photonic crystal. International Journal of Construction Management, 17(2), 100-112. 